\title{
The Correlation between Human papillomavirus and Increased Expression of p53 in Seborrheic Keratosis
}

\author{
Fesdia Sari, Sri Lestari, Rina Gustia, Ennesta Asri, Tofrizal \\ Department of Dermatology and Venereology, Faculty of Medicine Andalas University/Dr. M. Djamil \\ Hospital, Padang, Indonesia
}

\begin{abstract}
Background: Seborrheic keratosis is a benign epidermal skin tumor caused by sun exposure, virus, and genetic factor. Human papillomavirus (HPV) infection presumed to have an important role in seborrheic keratosis. Protein p53 is a protein produced by tumor suppressor gene. There has been no research that correlates of HPV with p53 increase in seborrheic keratosis. Purpose: To prove the correlation between HPV and increased p53 expression in seborrheic keratosis. Methods: This study is an analytic cross-sectional comparative study. Samples were taken using a consecutive sampling method. There were 22 seborrheic keratosis patients recruited as the research sample. HPV were detected using the polymerase chain reaction (PCR), and p53 expression were detected using the immunohistochemistry examination. Result: The mean age of seborrheic keratosis patients in this study was $54.36 \pm 10.09$ years, and they were predominantly males $(54.5 \%)$. HPV were found in $86.4 \%$ of the seborrheic keratosis patients. The P53 expression (+) were 77.3\%, $(++)$ were $13.6 \%$, and $(+++)$ were $9.1 \%$. All of the seborrheic keratosis with increased $\mathrm{p} 53$ expression had positive HPV results, but with no significant results $(\mathrm{p}=0.600)$. Conclusion: There were no correlation between HPV with increased p53 expression in seborrheic keratosis patients.
\end{abstract}

Keywords: HPV, p53 protein, seborrheic keratosis.

Correspondence: Fesdia Sari, Department of Dermatovenereology Faculty of Medicine Andalas University/Dr. M. Djamil Hospital, Padang, Jl. Perintis Kemerdekaan No. Jati Padang, 60131, Indonesia. Phone +62751, email: dia_fs@yahoo.com.

\section{BACKGROUND}

Seborrheic keratosis is a benign epidermal tumor usually found at the age of 50 years and above, affecting both men and women. It typically starts as a flat lesion, light to dark brown in color, welldemarcated with a smooth or hyperkeratotic surface. Seborrheic keratosis can occur in the various body area, although it typically occurs in heavily sun-exposed skin areas, especially the face and upper body.,

Most patients seek treatment for cosmetical reasons and local irritation, mainly on multiple lesions on the face. Seborrheic keratosis lesions should be differentiated from other types of skin tumors, either benign or malignant. A dark-colored seborrheic keratosis might resemble a malignant melanoma; such doubtful cases require histopathological examination to confirm the diagnosis. ${ }^{3}$

Chellamaiah reported that the incidence of seborrheic keratosis is $14 \%$ of all head and neck skin tumors. ${ }^{4}$ Furthermore, a study by Rajeev in India, there were 84 seborrheic keratosis cases $(42 \%)$ out of 200 patients older than 60 years old, making it the second most common benign tumor after cherry angioma. ${ }^{5}$ In Dr. M. Djamil Hospital, Padang, there were 29.7\% seborrheic keratosis cases out of 266 benign skin tumor cases in 2014-2017 (non-publication).

The exact cause of seborrheic keratosis is still unclear, althought the risk increases with age. Genetic, sun exposure, and infection are suspected as the causative factors. ${ }^{6}$ Recurrence can also occur after removal of seboorheic keratosis, but there has been no report on the percentage of recurrence in seborrrheic keratosis. $^{3}$

Seborrheic keratosis is also presumed to be related to malignancy, particularly basal cell carcinoma. Ishida reported a case of basal cell carcinoma emerging from seborrheic keratosis lesion, along with increased p53 protein expression in its immunohistochemistry evaluation. ${ }^{7}$ Likewise, study in Turkey reported a case of basal cell carcinoma arising from seborrheic keratosis and found an increase in the p53 protein expression. ${ }^{8}$ These findings further deepen the assumption that basal cell carcinoma is pathogenetically related to seborrheic keratosis. ${ }^{7,8}$

There is a hypothesis that Human papillomavirus (HPV) infection plays a role in the occurrence of seborrheic keratosis. ${ }^{6,9}$. Study in Japan) reported the presence of HPV in $28,8 \%$ of seborrheic keratosis lesions. While study in China found 42 out of 55 (76\%) cases of seborrheic keratosis containing HPV examined by polymerase chain reaction (PCR). The same study further reported type $20 \mathrm{HPV}$ as the most commonly found type, followed by type 23 , and type $5 .{ }^{10}$ Study in German found $52.4 \%$ seborrheic keratosis 
cases infected with HPV, in which types 4, 65, 6,15, 1, 38 and $95 \mathrm{HPV}$ were frequently found. ${ }^{11}$ In a study by Jeong found that $37.5 \%$ of seborrheic keratoses contain HPV DNA, comprising types 20, 23, 5, 16, 17, 22, 25, and $37 \mathrm{HPV}$ as the most frequently found. ${ }^{12}$ Most cutaneous HPVs are a part of the beta and gamma genus. Currently, there are 40 beta-genus HPV and 50 gamma-genus HPV types isolated. ${ }^{13,14,15}$

The correlation between HPV and malignancy has been clearly proven in the case of cervical, penile, vulvar, vaginal, anal, and oropharyngeal malignancy, as well as squamous cell carcinoma on the face and neck. However, the role of HPV in skin malignancy is, to date, still under study. HPV infection plays a role in the early phase of cutaneous carcinogenesis and has a synergistic effect with ultraviolet light that the virus is abundantly found in pre-malignant lesions. The role of HPV in skin malignancy is first described in an epidermodysplasia verruciformis that developed into a squamous cell carcinoma. ${ }^{16}$ A study by Conic reported 162 cases of squamous cell carcinoma that originated from keratosis. It is presumed that HPV has a part in such cases. ${ }^{17}$

The $\mathrm{p} 53$ protein is produced by the p53 tumor suppressor gene. P53 is activated as a response to various cellular stress; therefore, p53 acts as a guard for genomes, inhibiting the expansion and proliferation of various damaged cells. ${ }^{18}$ The p53 protein is present in almost all cells, although its amount is low and undetected under normal circumstances. The activation of $\mathrm{p} 53$ protein represents a mutation in gene p53, causing an accumulation of $\mathrm{p} 53$ protein to the point that it is immunohistochemically detectable. ${ }^{18,19}$

\section{METHODS}

This is an observational, cross-sectional study that aimed to prove the correlation between HPV and the increase in p53 protein expression in seborrheic keratosis. The inclusive criteria for samples were seborrheic keratosis patients older than 40 years old, and those who agreed to take part in the study by signing informed consent. The sole criterion was damaged paraffin blocks or histopathological examination unrepresentative for seborrheic keratosis. The samples were selected done with a consecutive sampling method, in which every inclusive patient was recruited as a subject until the required number of subjects is fulfilled. This study was conducted at the Dermatovenereology Department of Dr. M. Djamil Hospital, Padang, and has passed the ethical clearance from the ethics committee of DR. M. Djamil Hospital, Padang.

Total of 22 skin biopsy specimens collected with diagnosis seborrheic keratosis, the hematoxylin-eosin stained slides were reviewed to confirm the diagnosis. The tissue sample were cut in to two section, for immunohistochemistry and PCR. For the detection of p53 by immunohistochemistry (IHC), the paraffin blocks were cut $4 \mu \mathrm{m}$ tissue sections and stained with the p53 antibody monoclonal (Santa Cruz SC-126) 1:100 dilution. The whole IHC staining process, including the deparaffinization and antigen revealing procedures, was performed manually. The sections were examined under light microscopy . The assessment of immunostaining, a semi-quantitative approach was used based on the proportion of positively stained cells as follows: $(+) \leq 5 \%$ of positive cells; $(++) 5-30 \%$ of positive cells; and $(+++) \geq 30 \%$ of positive cells.

All PCR reactions were run in GeneAmp PCR System C1000 Touch ${ }^{\mathrm{TM}}$ Thermal Cycler (Bio Rad, USA). Amplicons were analyzed by electrophoresis in $1,5 \%$ agarose gel using ethidium bromide staining. The appearance of the 150 base-pair band, similar to positive control for L1 gene is considered as a positive result.

\section{RESULT}

The most seborrheic keratosis patients came from $\geq 50-59$ years $(40.9 \%)$ age group with the mean age of $54.36 \pm 10.09$ years, and they were mostly males (54.5\%), as shown in Table 1 . There were $86.4 \%$ HPVpositive patients, as shown in Table 2. As for the p53 protein in seborrheic keratosis, most samples were positive $(+)$, which was $77.3 \%$. Also, there was an increase in p53 expression, which was $(++)$ in $13.6 \%$ of subjects and $(+++)$ in $9.1 \%$ of subjects (Table 3 ). The correlation between HPV and increased p53 level in seborrheic keratosis. The seborrheic keratosis patients with increased p53 levels were all HPVpositive; however, this finding is not statistically significant $(p=0.6)$ (Table 4).

Table 1. The distribution of subjects based on age and sex

\begin{tabular}{|c|c|c|c|}
\hline \multicolumn{2}{|r|}{ Characteristic } & $\mathrm{f}$ & $\%$ \\
\hline \multicolumn{4}{|c|}{ 1. Age } \\
\hline \multicolumn{2}{|r|}{$40-49$ years } & 8 & 36.4 \\
\hline \multicolumn{2}{|r|}{$\geq 50-59$ years } & 9 & 40.9 \\
\hline \multirow{2}{*}{\multicolumn{2}{|c|}{$\begin{array}{l}\geq 60 \text { years } \\
\text { mean } \pm \mathrm{SD}\end{array}$}} & 5 & 22.7 \\
\hline & & $54.36 \pm 10.09$ & \\
\hline \multicolumn{4}{|c|}{ Sex } \\
\hline & - $\quad$ Male & 12 & 54.5 \\
\hline & - $\quad$ Female & 10 & 45.5 \\
\hline
\end{tabular}

*SD: Standard deviation 
Table 2. The Human papillomavirus status in seborrheic keratosis

\begin{tabular}{lccccccc}
\hline \multirow{2}{*}{ HPV } & \multicolumn{6}{c}{$\mathrm{P} 53$} & \multirow{2}{*}{$(+)$} \\
\cline { 2 - 6 } & \multicolumn{2}{c}{$(+)$} & \multicolumn{2}{c}{$(+++)$} & \\
\cline { 2 - 6 } & $\mathrm{F}$ & $\%$ & $\mathrm{~F}$ & $\%$ & $\mathrm{f}$ & $\%$ & \\
\hline Positive & 14 & 73.7 & 3 & 15.8 & 2 & 10.5 & 0.6 \\
Negative & 3 & 100 & 0 & 0.0 & 0 & 0.0 & \\
\hline *HPV: Human papilomavirus
\end{tabular}

*HPV: Human papilomavirus

\section{DISCUSSION}

The mean age of seborrheic keratosis patients was $54.36 \pm 10.09$ years, with the majority coming from the $\geq 50-59$ age group (40.9\%). A study by Roh found that the mean age of seborrheic keratosis patients was 60.1 \pm 14.3 years. ${ }^{1}$ Furthermore, a study by Rajesh on 250 seborrheic keratosis patients found that 50.2\% of subjects were $40-60$ years old, $32.7 \%$ were $21-40$ years old, $13.5 \%$ were $61-80$ years old, and only $2.8 \%$ were $<20$ years old. ${ }^{2}$

Seborrheic keratosis is a skin disorder that usually occurs as one gets older, and it is mostly found in individuals aged 50 years and above. The prevalence of seborrheic keratosis in the 50-59 age group is $69 \%$, $80 \%$ in the $60-69$ age group, and $90 \%$ in the $70-79$ age group. ${ }^{3}$

Table 3. The incidence of p53 protein expression in seborrheic keratosis

\begin{tabular}{ccc}
\hline P53 & $\mathrm{f}$ & $\%$ \\
\hline$(+)$ & 17 & 77.3 \\
$(++)$ & 3 & 13.6 \\
$(+++)$ & 2 & 9.1 \\
\hline
\end{tabular}

Notes:

$(+) \quad: \leq 5 \%$ of positive cells

$(++) \quad: 5-30 \%$ of positive cells

$(+++) \quad:>30 \%$ of positive cells

Although the etiology of seborrheic keratosis is not yet known, sun exposure presumably plays a role in the occurrence of seborrheic keratosis. Therefore, with increasing age, the exposure to sunlight is longer and the incidence of seborrheic keratosis increases. ${ }^{1}$ However, in this study, the incidence of seborrheic keratosis was low in patients aged $\geq 60$ years, because the older they were, the less they paid attention to their appearance. However, the results of this study cannot yet represent the epidemiological picture because of the small sample size.

Based on the results of this study, seborrheic keratosis was found more in males $(54.5 \%)$. This is in line with a research conducted by Roh where males $(53.06 \%)$ were found to have more seborrheic keratosis than females. It was likely caused by males doing more activities outside the house than females, so they were more often exposed to the sunlight. ${ }^{1}$

Table 4. The correlation between HPV and increased p53 protein expression in seborrheic keratosis

\begin{tabular}{ccc}
\hline HPV & $\mathrm{f}$ & $\%$ \\
\hline Positive & 19 & 86.4 \\
Negative & 3 & 13.6 \\
\hline
\end{tabular}

\section{Notes:}

(+) $\quad: \leq 5 \%$ of positive cells

$(++) \quad: 5-30 \%$ of positive cells

$(+++) \quad:>30 \%$ of positive cells

*HPV: Human papilomavirus

There were $86.4 \%$ HPV-positive seborrheic keratosis patients in this study. This number was a bit higher than those in previous reports. Study by $\mathrm{Li}$ reported that 42 out of $55(76 \%)$ seborrheic keratosis cases, after being evaluated with PCR, contained HPV DNA. ${ }^{10}$ Study in Germany found that $52.4 \%$ of seborrheic keratosis cases contained HPV, in which types $4,65,6,15,1,38$, and $95 \mathrm{HPV}$ were the most common. ${ }^{11}$ Furthermore, Gushi A found only 28.8\% seborrheic keratosis lesions bear HPV deoxyribonucleic acid (DNA). ${ }^{20}$

In an immunohistochemistry examination, the expression of $\mathrm{p} 53$ protein is either negative or positive. It is negative when there is none at all, while a browncolored cell means a positive result. In seborrheic keratosis, the expression of p53 and Bcl-2 alters, although the chromosome is not damaged. ${ }^{6}$ Naruke reported that $60 \%$ of cases of alteration in p53 as a response to DNA damage in seborrheic keratosis. ${ }^{19}$ The p53 protein was detectable in all seborrheic keratosis cases, reflecting the presence of DNA damage. The p53 protein triggers cells to enter the G1 phase in the cell cycle to repair the DNA damage and apoptosis process. ${ }^{21}$

Study by Brown found the immunohistochemistry aspects of p53 protein in squamous cell carcinoma, seborrheic keratosis, and verruca vulgaris. In this study, the p53 protein expression was positive in all seborrheic keratosis lesions and some even exhibit an increase in p53 expression. $^{22}$

In the pathogenesis of skin malignancy, HPV plays its part in the early phases of malignancy and acts as a co-carcinogen with ultraviolet (UV) rays by aggravating DNA damage. Thus, HPV is abundantly found in pre-malignant lesions as well as benign skin tumors. Seborrheic keratosis is a benign skin tumor; therefore, the chance to detect HPV is high. ${ }^{23}$ The results of this study further indicate the role of HPV in seborrheic keratosis. 
The results of this study revealed that the most seborrheic keratosis cases had positive $(+)$ p53 (77.3\%), while $13.6 \%$ were positive $(++)$, and only the remaining $9.1 \%$ cases had positive $(+++)$ result.

A study by Brown reported that of 10 seborrheic keratosis samples evaluated for p53 with immunohistochemistry examination, 6 samples $(60 \%)$ were positive $(+)$, and 4 samples $(40 \%)$ were positive $(++) .{ }^{22}$ Another study by Ko reported that of 10 evaluated seborrheic keratoses, the mean value of p53 protein expression was 2.1. This study grouped the value of p53 into 3 sections, 1 if p53 was found in less than $10 \%$ cells, 2 if p53 was found between $10 \%-30 \%$ cells, and 3 if p53 was found in more than $30 \%$ cells. $^{21}$

The p53 protein is produced by the tumor suppressor gene that inhibits the occurrence of malignancy by triggering apoptosis or halting the cell cycle when there is DNA damage. The p53 gene mutation dismisses gene p53 activity and cuts off signals for $\mathrm{p} 53$. The detected $\mathrm{p} 53$ proteins in immunohistochemistry coloration are abnormal or mutated $\mathrm{p} 53 .^{18}$

Terada in Japan reported a case of Bowen's disease emerging from seborrheic keratosis. The examined tissue exhibited tumor cells on the center with seborrheic keratosis features, and more than $30 \%$ of the cells were positively colored with p53 antibody in immunohistochemistry coloration. ${ }^{24}$ This study found seborrheic keratosis cases with increased p53 expression, hence the tendency to develop into a malignancy.

There are a number of factors that play a role in the development of skin malignancy, namely UV light, and viral infection. The HPV viral infection is cocarcinogenic with sunlight; the presence of HPV aggravates the already damaged DNA. In this report, all seborrheic keratosis cases with increased p53 were all HPV-positive, although this finding was not statistically significant $(p=0.6)$. The increased p53 expression was likely caused by exposure to sunlight.

A study by Tooth examined the correlation between HPV and p53 in 23 conjunctival squamous cell carcinoma patients and reported that $17 \%$ of samples were positive for HPV and p53; however, this finding was not statistically significant as well. ${ }^{25}$

The correlation between HPV and increased p53 expression has been proved in squamous cell carcinoma. A study in Sweden found the correlation between HPV infection and p53 expression in head and neck tumors. Cases of HPV-positive tumors with low p53 expression have a better prognosis than that of HPV-positive tumors with high p53 expression. ${ }^{26}$ Study by Hay also reported the correlation between HPV infection with p53 protein in vulvar squamous cell carcinoma. The presence of HPV and p53 protein reflects poor prognosis in patients with squamous cell carcinoma, as well as the tendency for recurrence. ${ }^{27}$

This study found that HPV was detected in most seborrheic keratosis patients, as well as an increase in p53 expression. Accordingly, it is advised to do curettage in addition to electrocauterization in seborrheic keratosis treatment. Further study is needed to evaluate other factors that trigger increased p53 protein expression in seborrheic keratosis.

\section{REFERENCES}

1. Roh N, Hahn H, Lee Y, Choe Y, Ahn K. Clinical and histopathological investigation of seborrheic keratosis. Ann Dermatol. 2016;28(2):152-158.

2. Thappa D, Rajesh G, Jaisankar T. Spectrum of seborrheic keratoses in South Indians: A clinical and dermoscopic study. Indian $J$ of Dermatol Venereol Leprol. 2011;77(4):483-8.

3. Hafner C, Vogt T. Seborrheic keratosis. Journal Der Deutschen Dermatologischen Gesellschaft. 2008;6(8):664-677.

4. Chellamaiah V, Vijayalakshmi B, Manoharan K. Clinico-pathological study of cutaneous tumours of head \& neck. $J$ Evolution Med Dent Sci. 2017;6(3):238-244.

5. Rajeev S, Singh S. A Clinicoepidemiological study of cutaneous manifestations in geriatric age group. J Evolution Med Dent Sci. 2017;6(68):4831-4841.

6. Thomas VD, Snavely, Lee KK, Swanson Na. Benign epithelial tumors, hamartomas, and hyperplasias. Dalam: Wolff K, Goldsmith LA, Katz SI, Gilchrest BA, Paller AS, penyunting. Fitzpatrick's Dermatology in General Medicine. Edisi ke-8. New York: McGraw-Hill Companies; 2012:1319-1323.

7. Ishida M, Ohsato N, Okabe H. Basal cell carcinoma arising within a seborrheic keratosis with respect to immunohistochemical characteristics. Oncology Letters. 2011;2(4):625-627.

8. Bedir R, Yurdakul C, Gucer H, Sehitoglu I. Basal cell carcinoma arising within seborrheic keratosis. J Clin Diagnostic Res.2014;8(7):6-7.

9. Brodsky J. Management of benign skin lesions commonly affecting the face: actinic keratosis , seborrheic keratosis, and rosacea. Curr Opin Otol\&Head and Neck Surgery. 2009;17(4):315320.

10. Li Y, Chen G, Dong X, Chen H. Detection of epidermodysplasia verruciformis-associated human papillomavirus DNA in nongenital seborrhoeic keratosis. $\mathrm{Br} J$ Dermatol. 2004;151(5):1060-1065.

11. Lally A, Casabonne D, Waterboer T, ImkoWalczuk B, Michael K, Pawlita $M$ et al. 
Association of seborrhoeic warts with skin cancer in renal transplant recipients. Journal of the European Academy of Dermatology and Venereology. 2010;24(3):302-307.

12. Jeong Y, Lee W, Bak H, Oh S, Jung H, Chang S et al. Detection of human papilloma virus DNA in seborrheic keratosis of korean skin. Ann Dermatol. 2007;19(3):99-105.

13. Accardi R, Gheit T. Cutaneous HPV and skin cancer. La Press Medicale. 2014;43(12):e435-e443.

14. Ibrahim F. Virologi human papillomavirus. Dalam: Andrijono, Indriatmi W, penyunting. Infeksi Human Papillomavirus. Edisi ke-1. Jakarta: Badan Penerbit Fakultas Kedokteran Universitas Indonesia. 2013;3-13.

15. Androphy EJ, Kirnbauer R. Human papilloma virus infections. Dalam: Wolff K, Goldsmith LA, Katz SI, Gilchrest BA, Paller AS, penyunting. Fitzpatrick's Dermatology in General Medicine. Edisi ke-8. New York: McGraw-Hill Companies;2012:2421-2433.

16. Drvar DL, Lipozenčić J, Sabol I, Mokos ZB, Ilic I, Grce M. Human papillomavirus status in extragenital nonmelanoma skin cancers. Clin Dermatol. 2014;32(2):248-252.

17. Conic RZ, Napekoski K, Schuetz, Piliang M, Bergfeld W, Atanaskova MN. The role of immunosuppression in squamous cell carcinoma arising in seborrheic keratosis. J Am Acad Dermatol.2017;76(6):1146-1150.

18. Batinac T, Gruber F, Lipozencic, Koncar GZ, Stasic A, Brajac I. Protein p53-structure, function, and possible therapeutic implications. Acta Dermatovenereology Croatia. 2003;(4):225-230.

19. Naruke Y, Nakashima M, Suzuki K. Alteration of p53-binding protein 1 expression during skin carcinogenesis: Association with genomic instability. Cancer Sci. 2008;99(5):946-951.
20. Gushi A, Kanekura T, Kanzaki T, Eizuru Y. Detection and sequences of human papillomavirus DNA in nongenital seborrheic keratosis. $J$ Dermatol Sci. 2003;31(2):143-149.

21. Ko C, Binder S. Comparison of seborrheic keratoses, inflamed seborrheic keratoses, and inverted follicular keratoses using P53, BCL-1, and BCL-2. J Cutan Pathol. 2008;32(1):98-98.

22. A Brown R, Kim J. Evaluation of invasive squamous cell carcinoma, seborrheic keratosis and verruca vulgaris in superficial shave biopsies using p16, p53, p63, and PHLDA1 immunohistochemistry. J Clin Exp Dermatol Res. 2016;07(03):1-6.

23. Venuti A, Lohse S, Tommasino M, Smola S. Crosstalk of cutaneous beta human papillomaviruses and the immune system: Determinants of disease penetrance. Philosophical Transactions of the Royal Society B: Biological Sciences. 2019;374(1773):1-7.

24. Terada T. Pigmented Bowen disease arising in pigmented reticulated seborrheic keratosis. Int $J$ Clin Oncol. 2010;15(6):608-610.

25. Toth J, Karcioglu Z, Moshfeghi A, Issa T, AlMa'ani J, Patel K. The relationship between human papillomavirus and p53 gene in conjunctival squamous cell carcinoma. Cornea. 2000;19(2):159-162.

26. Sivars L, Näsman A, Tertipis N, Vlastos A, Ramqvist $\mathrm{T}$, Danialis $\mathrm{T}$ et al. Human papillomavirus and p53 expression in cancer of unknown primary in the head and neck region in relation to clinical outcome. Cancer Med. 2014;3(2):376-384.

27. Hay C, Lachance J, Lucas F, Smith K, Jones M. Biomarkers p16, human papillomavirus and p53 predict recurrence and survival in early stage squamous cell carcinoma of the vulva. J Low Genit Tract Dis. 2016;20(3):252-256 